\title{
PENENTUAN HARGA PREMI ASURANSI PERTANIAN BERBASIS INDEKS CURAH HUJAN DENGAN MENGGUNAKAN METODE PEMBANGKIT DISTRIBUSI EKSPONENSIAL CAMPURAN
}

\author{
Sayid Qosim ${ }^{1}$, Komang Dharmawan ${ }^{2} \S$, Luh Putu Ida Harini ${ }^{3}$ \\ ${ }^{1}$ Jurusan Matematika, FMIPA - Universitas Udayana [Email: sayqosim@ gmail.com] \\ ${ }^{2}$ Jurusan Matematika, FMIPA - Universitas Udayana [Email: dharmawan.komang@gmail.com] \\ ${ }^{3}$ Jurusan Matematika, FMIPA - Universitas Udayana [Email: ballidah@ gmail.com] \\ $\S$ Corresponding Author
}

\begin{abstract}
Agricultural insurance is an insurance in agriculture sector that is relatively newly introduced in Indonesia. Agricultural insurance based on rainfall index is one of the risk management tool to keep farmers in case of crop failure. This study aims to determine the steps in determining the value of rainfall index on agricultural insurance and calculate the value of agricultural insurance premiums based on simulated rainfall index by Stochastic weather generator with mixed exponential distribution. The results of this study provide value if the amount of rainfall 103,71 $\mathrm{mm}$ so that the amount of premium payments equal to Rp19.016, and if the rainfall is high $128.35 \mathrm{~mm}$ then the amount of premium payment equal to Rp1.088.000.
\end{abstract}

Keywords : Agricultural Insurance, Rainfall Index, Stochastic weather generator, Opsi Put Cash-orNothing

\section{PENDAHULUAN}

Sektor pertanian adalah salah satu jenis usaha dengan risiko ketidakpastiannya cukup tinggi. Sumber risiko dan ketidakpastian yang bersifat eksternal atau yang tidak dapat dikendalikan oleh petani umumnya berasal dari lingkungan alam (iklim, bencana alam, ataupun organisme penganggu tanaman).

Salah satu tantangan yang dihadapi oleh masyarakat dunia khususnya petani adalah perubahan iklim. IPCC (2007) mendefinisikan perubahan iklim adalah setiap perubahan terhadap iklim yang disebabkan oleh variabilitas alami maupun aktivitas manusia. Subsektor dari pertanian yang rentan akan perubahan iklim adalah tanaman pangan, karena tanaman pangan umumnya merupakan tanaman semusim yang berakar dangkal.

Menurut Undang-Undang No 19 tahun 2013, tentang perlindungan dan pemberdayaan petani psal 37 ayat (1), “ Pemerintah dan
Pemerintah Daerah sesuai dengan kewenangannya berkewajiban melindungi usaha tani yang dilakukan oleh petani dalam bentuk asuransi pertanian”. Sebagai wujud dari pelaksanaan undang-undang tersebut, pemerintah melalui Kementrian Keuangan, Badan Kebijakan Fiskal, Pusat Risiko Fiskal telah memulai melakukan kajian implementasi asuransi pertanian secara nasional.

Asuransi pertanian ditawarkan sebagai salah satu solusi untuk membantu petani Indonesia. Asuransi pertanian bukan istilah baru dalam sektor pertanian di banyak negara, khususnya di negara maju yang telah menggunakan instrumen kebijakan asuransi untuk menjaga produksi pertanian dan melindungi petani.

Penelitian terkait asuransi pertanian telah dikaji sebelumnya. Salah satunya adalah (Putri, et al., 2017) dalam penelitiannya yaitu menghitung premi asuransi pertanian berbasis 
indeks curah hujan menggunakan metode black scholes dengan mengambil komoditas padi sebagai objek penelitiannya.

Tujuan penelitian ini adalah mengetahui prosedur penentuan indeks curah hujan dengan menggunakan Stochastic weather generator dan mengetahui nilai premi asuransi pertanian berbasis indeks curah hujan yang fair.

Stochastic weather generator adalah algoritma komputer yang menggunakan catatan meteorologi yang ada untuk menghasilkan rangkaian panjang data cuaca dan memiliki sifat statistik serupa dengan data yang diamati (Chen, et al., 2010). Langkah yang dilakukan untuk simulasi Stochastic weather generator yaitu dengan mencari nilai probabilitas transisi pada rantai Markov kemudian pemdodelan curah hujannya dengan menggunakan distrubusi yang umum. Pada penelitian ini menggunakan distribusi eksponensial campuran.

\section{Rantai Markov}

Rantai Markov dapat dilihat sebagai cara menggambarkan peluang dari suatu peristiwa yang terjadi tergantung hanya pada ruang yang dicapai dalam ruang sebelumnya. Studi ini telah mengadopsi dua ruang orde pertama Markov chain untuk mensimulasikan terjadinya curah hujan. Model ini ditandai dengan dua probabilitas transisi, $P_{01}$ probabilitas bulan basah didahului dengan bulan kering dan $P_{11}$ probabilitas bulan basah didahului oleh bulan basah, diungkapkan oleh persamaan (1) dan (2) masing-masing (Dlamini, et al., 2015).

$\mathrm{P}_{01}=\mathrm{P}\{$ bulan basah pada saat $t \mid$ bulan kering pada $t-1\}$,

$\mathrm{P}_{11}=\mathrm{P}\{$ bulan basah pada saat $t \mid$ bulan basah pada $t-1$.

Mensimulasikan terjadinya curah hujan $P_{S}(t)$ pada bulan $t$, nomor acak $U_{t}$ dihasilkan menggunakan Program MATLAB 2015 dan dibandingkan dengan probabilitas transisi kritis (persamaan 3) yang tergantung pada curah hujan keadaan bulan sebelumnya $t-1$ di mana bulan basah $=1$ dan bulan kering $=0$.

$$
P_{c}=\left\{\begin{array}{l}
P_{01} \text { if } P_{S}(t-1)=0, \\
P_{11} \text { if } P_{S}(t-1)=1 .
\end{array}\right.
$$

Bulan-bulan basah disimulasikan ketika nomor acak kurang dari probabilitas kritis (persamaan 4), selain itu disimulasikan sebagai bulan kering.

$$
P_{S}(t)=\left\{\begin{array}{l}
1 \text { if } U_{t} \leq P_{c}, \\
0 \text { if } U_{t}>P_{c} .
\end{array}\right.
$$

Dua probabilitas pelengkap lainnya untuk bulan kering setelah bulan kering dan bulan kering setelah bulan basah yakni dapat dilihat pada persamaan (5) dan (6).

$$
\begin{aligned}
& P_{00}=1-P_{01}, \\
& P_{10}=1-P_{11} .
\end{aligned}
$$

Probabilitas transisi dapat diperkirakan dari seri curah hujan yang diamati setiap bulan seperti pada tabel dibawah ini.

Tabel 1 Probabilitas Transisi Curah Hujan

\begin{tabular}{|c|c|c|c|c|}
\hline \multicolumn{2}{|c|}{} & \multicolumn{2}{|c|}{ Bulan ini } & \multirow{2}{*}{ Total } \\
\hline \multirow{2}{*}{$\begin{array}{c}\text { Bulan } \\
\text { Sebelumnya }\end{array}$} & $\begin{array}{c}\text { Kering } \\
(\mathbf{0})\end{array}$ & $\begin{array}{c}\text { Basah } \\
(\mathbf{1})\end{array}$ & \\
\cline { 2 - 5 } & $\mathbf{( 0 )}$ & $\mathrm{N}_{00}$ & $\mathrm{~N}_{01}$ & $\mathrm{~N}_{0}$ \\
\cline { 2 - 5 } & $\begin{array}{c}\text { Basah } \\
(\mathbf{1})\end{array}$ & $\mathrm{N}_{10}$ & $\mathrm{~N}_{11}$ & $\mathrm{~N}_{1}$ \\
\hline
\end{tabular}

dengan:

$N_{00}=$ Jumlah bulan kering didahului bulanbulan kering

$N_{01}=$ Jumlah bulan basah didahului bulanbulan kering

$N_{10}=$ Jumlah bulan kering didahului bulanbulan basah

$N_{11}=$ Jumlah bulan basah didahului bulanbulan basah

$N_{0}=$ Jumlah total bulan kering

$N_{1}=$ Jumlah total bulan basah

\section{Pemodelan Curah Hujan}

Pemodelan untuk menghasilkan jumlah curah hujan, dalam penelitian ini menggunakan distribusi eksponensial campuran.

$$
f(x)=\frac{p}{\mu_{1}} e^{\frac{-x}{\mu_{1}}}+\frac{1-p}{\mu_{2}} e^{\frac{-x}{\mu_{2}}}
$$

Untuk $\quad x>0,0<p<1,0<\mu_{1}<\mu_{2}$, dimana $f(x)$ adalah fungsi kepadatan peluang 
dan $p, \mu_{1}, \mu_{2}$ adalah parameternya. Nilai parameter diestimasi dengan maximum likelihood.

Selanjutnya, perhitungan permi asuransi pertanian menggunakan opsi put cash-ornothing yang secara umum digunakan yakni Black Scholes.

$$
\text { Premi }=\gamma e^{-r t} N\left(-d_{2}\right)
$$

dengan

$$
d_{2}=\frac{\ln \left(\frac{C_{0}}{C_{t}}\right)+\left(r-0.5 \sigma^{2}\right) t}{\sigma \sqrt{t}}
$$

Nilai $N\left(d_{2}\right)$ adalah peluang (risk-neutral) bahwa nilai $S_{t}$ akan melebihi $K$. Sehingga, $N\left(-d_{2}\right)$ adalah peluang (risk-neutral) bahwa harga saham akan lebih kecil dari harga tebus $K$ pada saat $t$, dan mengakibatkan nilai yang fair. (Dharmawan et al., 2016).

\section{METODE PENELITIAN}

\section{Sumber Data}

Sumber data yang digunakan dalam penelitian ini adalah data sekunder yaitu data curah hujan bulanan di Kecamatan Sidemen Kabupaten Karangasem selama 20 tahun, mulai tahun 1997 - 2016 yang diperoleh dari Badan Meteorologi dan Geofisika Provinsi Bali. Serta data hasil panen jagung catur wulan dari produksi pertanian di Kabupaten Karangasem selama 20 tahun mulai, tahun 1997-2016 dari Dinas Pertanian Provinsi Bali dan Badan Pusat Statistika Provinsi Bali.

\section{Teknis Analisis Data}

Langkah-langkah yang dilakukan dalam penelitian ini adalah sebagai berikut:

1. Mengindentifikasi keterkaitan tumbuhan jagung dan curah hujan serta memplot data historis hasil panen jagung.
2. Menghitung nilai-nilai probabilitas transisi curah hujan dan menghitung nilai parameternya.

3. Melakukan simulasi data curah hujan dengan menggunakan Stochastic weather generator.

4. Penentuan indeks curah hujan menggunakan data dari hasil simulasi Stochastic weather generator.

5. Menentukan harga pertanggungan asuransi pertanian berdasarkan pada biaya produksi, tenaga kerja dan operasional lainnya.

6. Menghitung premi asuransi pertanian.

\section{HASIL DAN PEMBAHASAN}

\section{Identifikasi Tumbuhan Jagung dengan Cura Hujan}

Salah satu faktor iklim adalah curah hujan, curah hujan berhubungan erat dengan ketersediaan air. Oleh sebab itu, air merupakan kebutuhan yang mutlak bagi tanaman jagung. Tanpa air tanaman jagung akan layu atau bahkan bisa mati. Pertumbuhan jagung sendiri memerlukan curah hujan ideal sekitar 85-200 $\mathrm{mm} / \mathrm{bulan}$.

Berikut ini disajikan plot data hasil produksi jagung tahun 1997 sampai dengan tahun 2016. Plot yang disajikan terbagi menjadi per-catur wulan, artinya plot catur wulan pertama dimulai dari mulai tahun 1997 - 2016, begitupun pada plot catur wulan kedua dan catur wulan ketiga. Deskripsi data historis Subround atau catur wulan tersebut dari Hasil Produksi Jagung di Kab. Karangasem periode 1997 - 2016 dapat dilihat pada Gambar 1. 


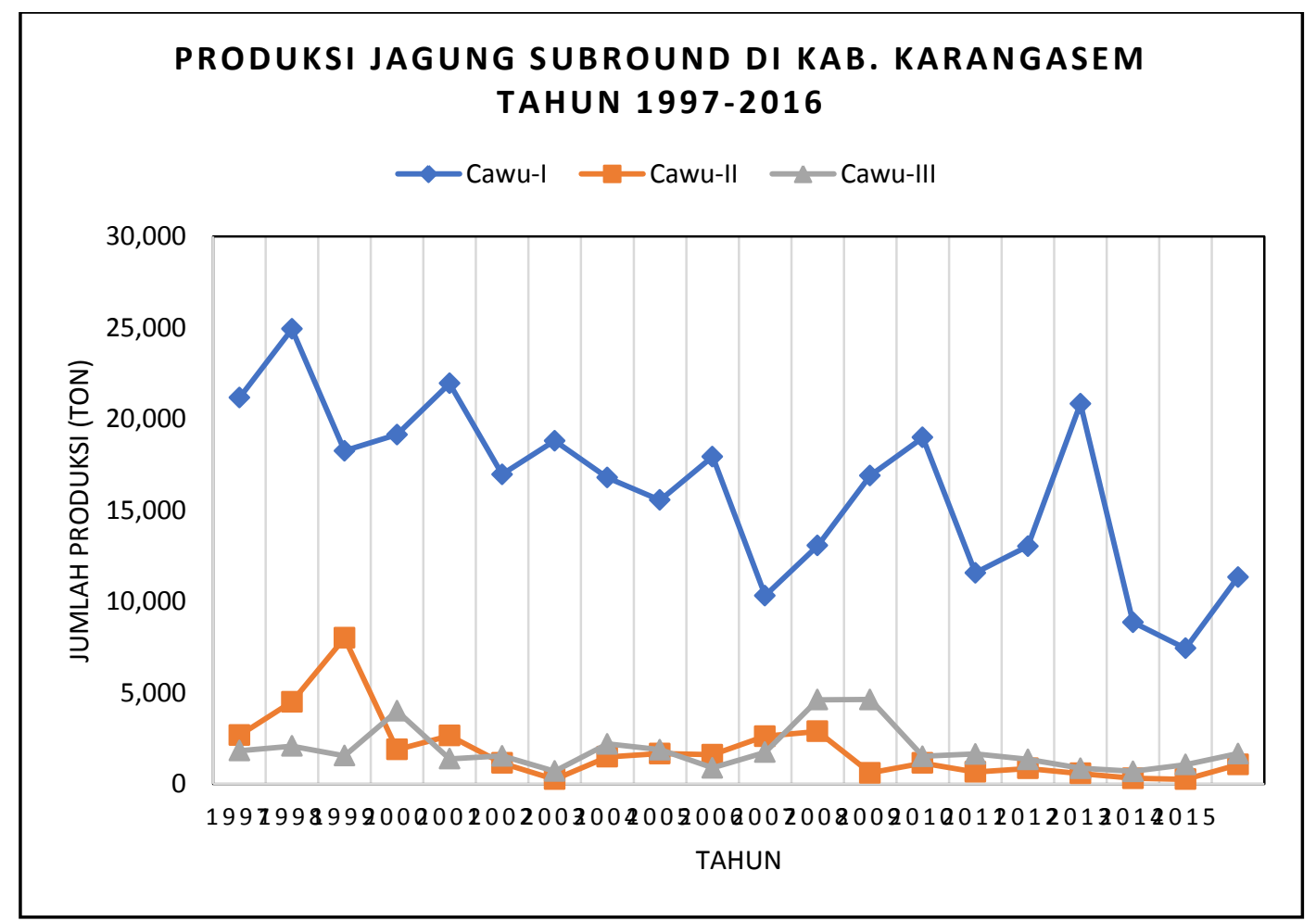

Gambar 1. Data Historis Produksi Jagung di Kab. Karangasem tahun 1997 - 2016

\section{Simulasi Stochastic weather generator}

Rangkaian simulasi Stochastic weather generator, diawali dengan mencari nilai peluang pada persamaan (1) dan (2). Untuk mensimulasikan terjadinya curah hujan $P_{S}(t)$ pada bulan $t$, nomor acak $U_{t}$ dihasilkan menggunakan Program MATLAB 2015 dan dibandingkan dengan probabilitas transisi kritis $P_{c}$ yang tergantung pada curah hujan keadaan bulan sebelumnya $t-1$ di mana bulan basah $=1$ dan bulan kering $=0$.

Tabel 2. Nilai Peluang Transisi

\begin{tabular}{|c|c|}
\hline Peluang & Nilai \\
\hline$P_{00}$ & 0,5455 \\
\hline$P_{01}$ & 0,4545 \\
\hline$P_{10}$ & 0,1734 \\
\hline$P_{11}$ & 0,8266 \\
\hline
\end{tabular}

Selanjutnya nilai dari $P_{01}$ dan $P_{11}$ akan disimulasikan dengan ditribusi eksponensial campuran untuk menghasilkan jumlah curah hujan dengan nilai paramaternya, $p=$ $6,18 \times 10^{-14}, \quad \mu_{1}=165,39, \quad \mu_{2}=220,46$. Simulasi dihitung dengan menggunakan program MATLAB 2015. Gambar 2 memperlihatkan hasil simulasi dari data curah hujan.

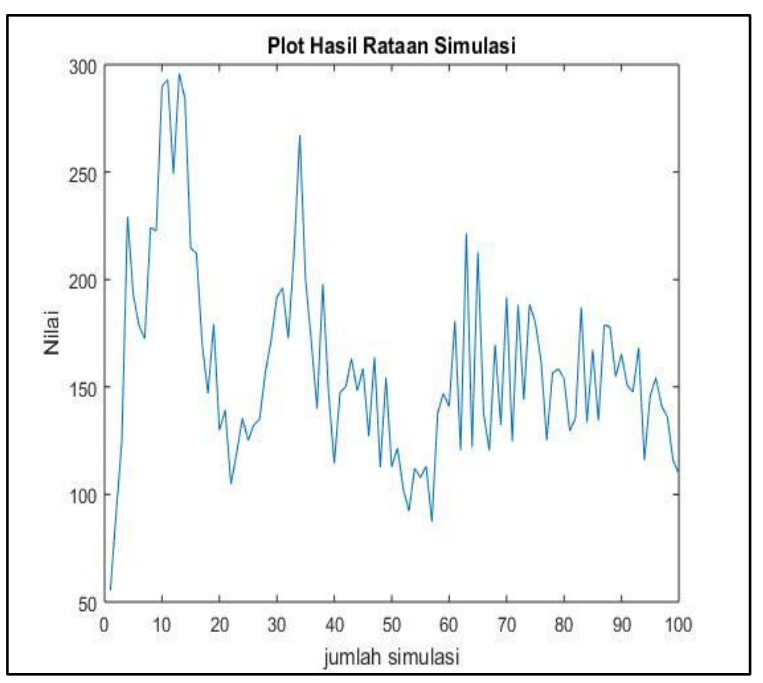

Gambar 2. Memperlihatkan Hasil Simulasi dari Data Curah Hujan

Dari hasil simulasi yang telah dilakukan, sehingga dapat ditentukan pemicu atau triggernya. Peristiwa pemicu (triggering event) adalah nilai patokan yang nantinya akan digunakan sebagai indeks curah hujan. 
Tabel 3. Nilai Trigger

\begin{tabular}{|l|c|}
\hline & Trigger \\
\hline Persentil ke-5 & 103,71 \\
\hline Persentil ke-10 & 112,81 \\
\hline Persentil ke-15 & 117,51 \\
\hline Persentil ke-20 & 123,17 \\
\hline Persentil ke-25 & 128,35 \\
\hline
\end{tabular}

Sumber : Data diolah tahunn 2017

\section{Uji Log Normalitas}

Uji log normalitas digunakan untuk mengetahui data berdistribusi log normal atau tidak. Pembahasan ini akan menggunakan uji Anderson Darling dengan taraf signifikan 0,05 . Data yang dinyatakan berdistribusi log normal jika signifikansi lebih besar 5\% atau 0,05 . Berikut grafik plot peluang pormal log data simulasi curah hujan.

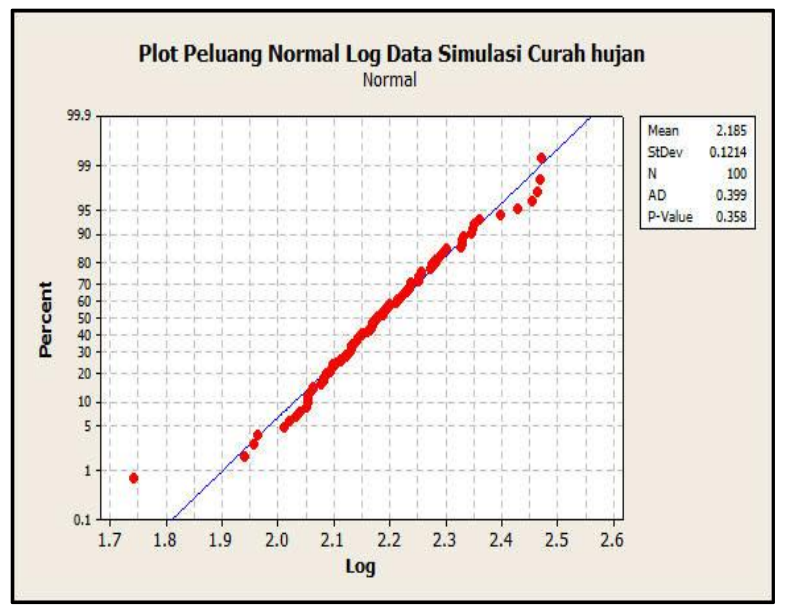

Gambar 3. Plot Kenormalan Data Simulasi

Curah Hujan

\section{Penentuan Harga Pertanggungan}

Menentukan suatu harga pertanggungan pada asuransi pertanian terhadap petani akibat perubahan curah hujan dapat dihitung berdasarkan biaya produksi seperti pembelian benih, biaya pupuk, tenaga kerja dan operasional lainnya. Berdasarkan biaya input tersebut, maka petani tersebut akan memperoleh nilai pertanggungan pada produksi jagung sebesar Rp7.735.000/Ha.

\section{Penentuan Harga Premi Asuransi Pertanian}

Tahapan selanjutnya adalah menghitung besarnya premi asuransi pertanian yang harus di bayarkan oleh petani menggunakan opsi put cash-or-nothing. Pemilik kontrak opsi put cash-or-nothing akan menerima sejumlah $\gamma$ rupiah saat kontrak jatuh tempo saat nilai $S_{t}$ lebih kecil dari indeks $K, S_{t}<\mathrm{K}$, atau akan menerima 0 (tidak menerima apapun) saat $S_{t} \geq K$. Implementasi perhitungan premi dengan penyesuaian di antaranya $C_{0}$ adalah harga mula-mula, dan $C_{t}$ adalah nilai trigger (K) diperoleh dari persentil data hasil simulasi komoditas jagung selama 20 tahun.

Perhitungan premi asuransi yang dapat digunakan adalah dengan cara menghitung menggunakan persamaan (8). Penentuan harga premi pada asuransi pertanian ini, akan dihitung untuk persentil ke-5, persentil ke-10, persentil ke-15, persentil ke-20, dan persentil ke-25. Pengambilan nilai persentil kecil bahwa diasumsikan jagung akan mati Karena kekurangan air. Nilai trigger ditentukan dari nilai persentil data curah hujan yang telah disimulasikan. Sehingga perhitungannya sebagai berikut :

dengan

$$
\text { Premi }=\gamma e^{-r t} N\left(-d_{2}\right)
$$

$$
d_{2}=\frac{\ln \left(\frac{C_{0}}{C_{t}}\right)+\left(r-0.5 \sigma^{2}\right) t}{\sigma \sqrt{t}}
$$

Hal yang harus dilakukan yakni terlebih dahulu menghitung fungsi distribusi kumulatif $d_{2}$. Diasumsikan suku bunga bebas risiko konstan $r=6,5 \%$ per tahun, $t=0,25$, dan $\sigma=0,245$. Variabel $S_{t}$ merupakan nilai patokan yang didefinisikan sebagai indeks yang dipilih. Nilai dari $S_{t}=5$ persentil dari hasil data simulasi adalah 103,71 $\mathrm{mm}$. Senhingga perhitugannya menjadi :

$$
\begin{gathered}
d_{2}=\frac{\ln \left(\frac{145}{103,71}\right)+\left(0,065-0,5(0,245)^{2}\right) 0,25}{0,245 \sqrt{0,25}} \\
d_{2}=2,8072 \\
N\left(-d_{2}\right)=0,0025
\end{gathered}
$$


Berdasarkan pada hasil perhitungan nilai patokan curah hujan atau $N\left(-d_{2}\right)$ persentil 5 yaitu sebesar 0,0025 , maka perhitungan premi yang harus dibayarkan saat nilai patokan curah hujan 5 persentil adalah sebagai berikut :

$$
\begin{aligned}
& \text { Premi }=R p .7 .735 .000 \times e^{-0,065 \times 0,25} \times 0,0025 \\
& =R p .19 .016
\end{aligned}
$$

Jadi premi yang harus dibayarkan saat persentil 5 adalah sebesar Rp19.016. Sedangkan untuk harga premi yang harus dibayarkan dengan nilai persentil yang berbeda dapat dilihat pada Tabel 4. berikut.

Tabel 4. Nilai Premi untuk Trigger yang Berbeda-beda

\begin{tabular}{|c|c|c|c|c|}
\hline $\begin{array}{c}\text { Perse- } \\
\text { ntil } \\
\text { Ke- }\end{array}$ & Trigger & $\begin{array}{c}\text { Pertanggu } \\
\text { ngan(Rp) }\end{array}$ & $\begin{array}{c}\text { Premi } \\
(\mathrm{Rp})\end{array}$ & $\%$ \\
\hline 5 & 103,71 & 7.735 .000 & 19.016 & 0,25 \\
\hline 10 & 112,81 & 7.735 .000 & 129.200 & 1,67 \\
\hline 15 & 117,51 & 7.735 .000 & 289.730 & 3,75 \\
\hline 20 & 123,17 & 7.735 .000 & 610.7300 & 7,89 \\
\hline 25 & 128,35 & 7.735 .000 & 1.088 .000 & 14 \\
\hline
\end{tabular}

Sumber: Data diolah tahun 2017

Menurut Insyafiah dan Wardhani (2014), Premi yang ditetapkan oleh pemerintah melalui uji coba yang dilakukan oleh Asuransi Usaha Tani Padi (AUTP) adalah sebesar 3\%. Sehingga apabila biaya total produksi sebesar Rp7.735.000, maka nilai preminya adalah Rp232.050. Namun pada perhitugan Tabel 4.4 dapat dilihat, bahwa nilai preminya lebih fleksibel. Artinya pada persentil 5 memberikan persentase $0,25 \%$ dengan nilai premi Rp19.016, pada persentil 10 memberikan presentase $1,67 \%$ dengan nilai premi 129.200 , dan semakin tinggi nilai persentil semakin tinggi juga nilai presentasenya serta nilai preminya.

\section{KESIMPULAN DAN SARAN}

\section{Kesimpulan}

Hasil penelitian dalam menentukan premi asuransi pertanian dapat disimpulkan sebagai berikut:

Stochastic weather generator digunakan untuk mensimulasi data curah hujan. Kemudian dari hasil simulasi ditentukan nilai trigger-nya, pada penelitian ini mengambil nilai persentil ke-5, 10, 20, dan 25. Data hasil simulasi juga di uji terlebih dahulu, karena pada penentuan premi dengan Black-Scholes mensyaratkan bahwa data berdistribusi log normal. Selanjutnya melakukan perhitungan premi dari nilai persentil-persentil yang diambil.

Kajian penelitian Asuransi Usaha Tani Padi (AUTP) oleh pemerintah menetapkan nilai premi sebesar 3\%, maka pembayaran preminya sebesar Rp.232.050. Sedangkan nilai premi asuransi pertanian menggunakan opsi put cash-or-nothing dengan simulasi Stochastic weather generator memberikan nilai premi yang lebih fair. Artinya apabila pertani memilih persentil ke-5 dengan nilai 103,71 sebagai nilai patokan trigger-nya, maka nilai premi yang dibayarkan sebesar Rp.19.016, kemudian apabila persentil ke-10 dengan nilai 112,81 maka premi yang dibayarkan sebesar Rp.129.200. Sehingga dapat dilihat bahwa perhitungan premi pada penelitian ini memberikan nilai yang fleksibel, semakin tinggi nilai trigger-nya maka semakin tinggi juga nilai premi yang dibayarkan.

\section{Saran}

Hal-hal yang dapat disarankan oleh penulis yaitu :

1. Pemerintah khususnya pihak asuransi pertanian harus mampu berkordinasi dengan pihak BMKG. Karena asuransi ini berkaitan dengan curah hujan

2. Petani mampu memilih produk asuransi pertanian dengan baik, sesuai dengan kondisi yang ada pada daerah masingmasing. 


\section{DAFTAR PUSTAKA}

Chen, J., Brissette, F. P. \& Leconte, R., 2010. A daily Stochastic weather generator for preserving low-frequency of climate variability. Journal of Hydrology, pp. 480-490.

Dharmawan, K., I W. Widia, \& Eswaryanti K.Y., L.P. 2016. Penerapan Metode Penilaian Kontrak Opsi dalam Penentuan Premi Asuransi Pertanian Berbasis Indeks Curah Hujan. Makalah Invited Speaker Pada Seminar Nasional Matematika XVIII Pekanbaru, Riau, 2-3 November 2016.

Dlamini, N., Lai, S., Rowshon, M. \& Syazwan, F., 2015. Developing And Calibrating Sthocastic Rainfall Generator Model For Simulating Daily. Jurnal Teknologi (Sciences \& Engineering), Volume 76:15(2015), pp. 13-19.
Insyafiah \& Wardhani, I., 2014. Kajian Implementasi Asuransi Pertanian Secara Nasional. Kementrian Keuangan Kebijakan Fiskal Pusat Pengelolaan Risiko Fiskal.

IPCC, 2007. Climate Change 2007: The Physical Science Basis. Summary for Policymakers. Geneva: Intergovermental Panel on Climate Change.

Putri, I.A.G.K., Dharmawan, K. \& Tastrawati, N.K.T., 2017. Perhitungan Harga Premi Asuransi Pertanian Berbasis Indeks Curah Hujan Menggunakan Metode Black Scholes. E-jurnal Matematika, Volume 6(2), pp. 161-167. 